\section{A 59-year-old woman with visible precordial pulsations}

\section{CLINICAL INTRODUCTION}

A retired 59-year-old woman presented to the cardiology clinic concerned with cardiac pulsations that were visible on her chest wall. These were not associated with dyspnoea, syncope or chest discomfort.

Of note, 8 years previously, she complained of recurrent nocturnal diaphoresis and $5 \mathrm{~kg}$ weight loss. Blood sampling at that time revealed a microcytic anaemia, reactive thrombocytosis and raised inflammatory markers (erythrocyte sedimentation rate $99 \mathrm{~mm} /$ hour, C-reactive protein $161 \mathrm{mg} / \mathrm{L}$ ). Following an episode of transient diplopia, ophthalmoscopy demonstrated a cotton wool spot in the left inferotemporal retinal arcade. She commenced a 2-year tapering course of $1 \mathrm{mg} / \mathrm{kg}$ prednisolone.
On examination, she had a lean physique with a supine blood pressure of $162 / 60 \mathrm{~mm} \mathrm{Hg}$ and palpable Corrigan's pulse. She had a prominent apical pulsation and a loud early diastolic murmur was present at the left sternal edge radiating to the apex. Echocardiography showed severe central aortic regurgitation and a dilated aortic root (see online supplementary figure 1). Cardiac CT was performed to clarify the diagnosis (figure 1).

\section{QUESTION}

Which of the following diagnoses best explains this presentation?
A. Ankylosing spondylitis
B. Takayasu arteritis
C. Salmonellosis
D. IgG4-related aortitis
E. Giant cell aortitis

For the answer see page 274
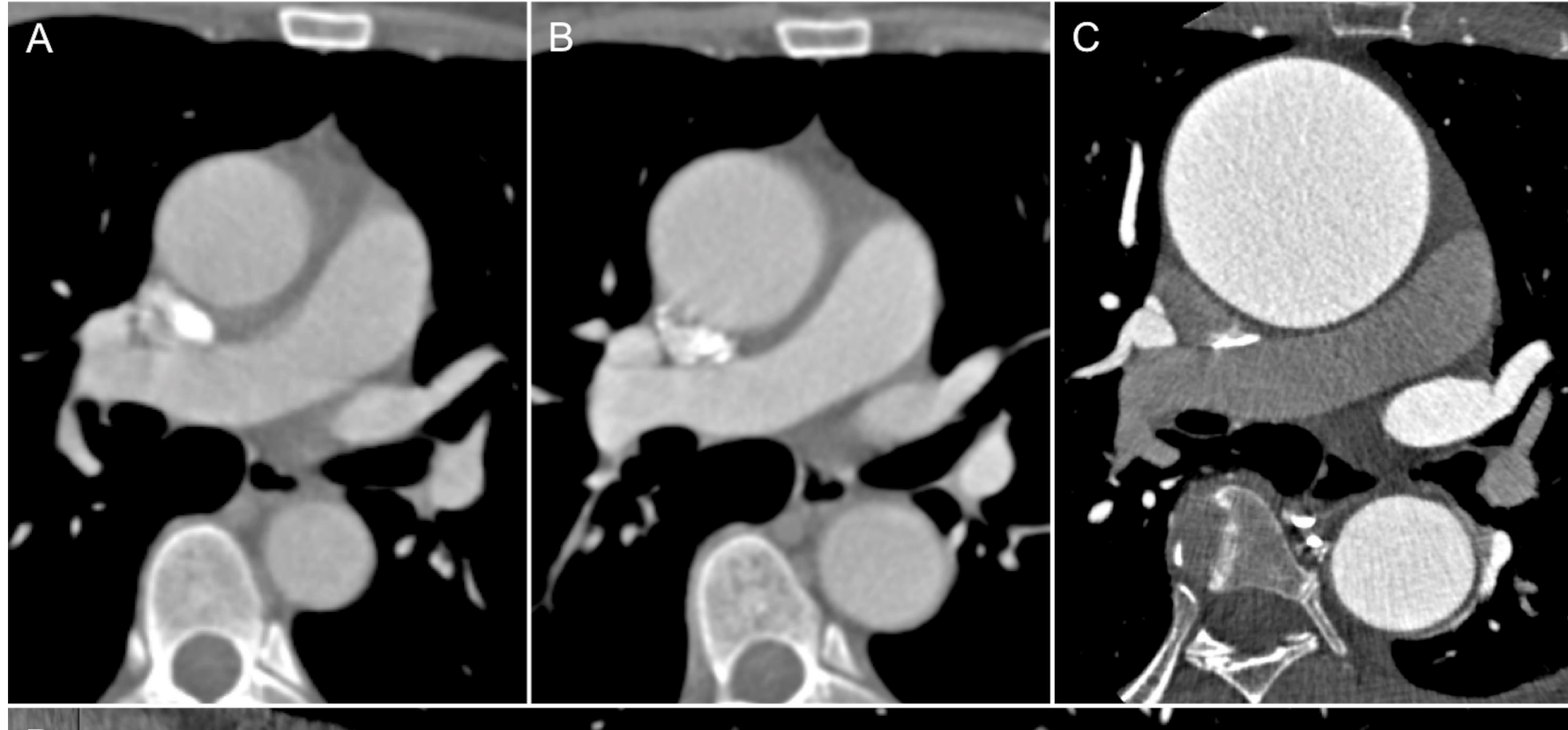

D
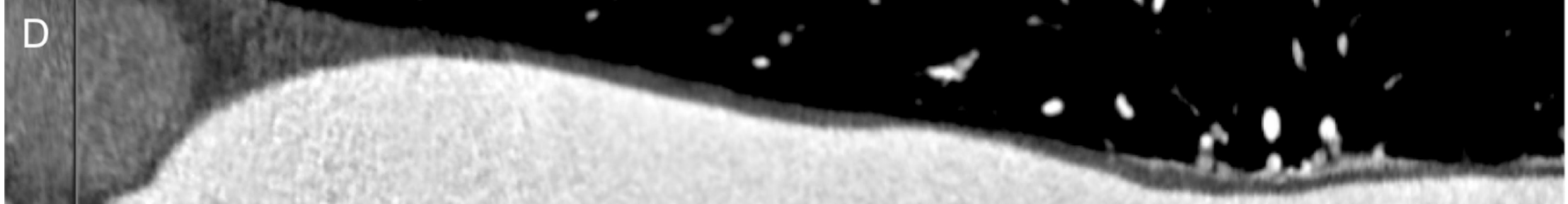

1

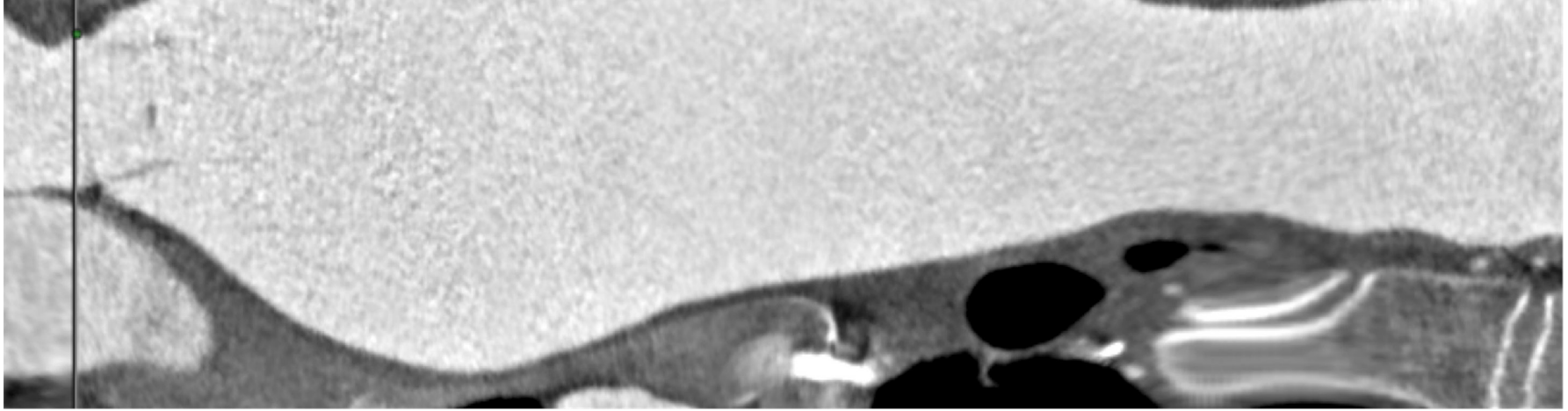

Figure 1 Contrast-enhanced CT of the thorax at index presentation (A) and 6 months (B). Prospective ECG-gated cardiac CT angiogram (75\% R-R interval) performed at 8 years from index presentation (C) with a stretched multiplanar reconstruction of the aortic annulus, aortic root and thoracic aorta (D). 


\section{A 59-year-old woman with visible precordial pulsations}

For the question see page 253

\section{Correct answer: $\mathrm{E}$}

The correct answer is giant cell aortitis. Progressive aortic ectasia is noted on serial imaging. The ECG-gated CT aortogram demonstrates an aortic annulus within normal limits, but there is severe dilatation of the aortic root. The proximal ascending aorta is severely aneurysmal (maximum diameter $77.5 \mathrm{~mm}$ ). The aortic arch and descending thoracic aorta show circumferential $4 \mathrm{~mm}$ intramural thickening in the absence of atheroma and with contrast enhancement of the adventitia (figure 2). The history of polymyalgia rheumatic and the CT pattern of annuloaortic ectasia in the presence of intramural thickening $(\geq 2 \mathrm{~mm}$ ) with adventitial contrast enhancement are compatible with giant cell aortitis. ${ }^{1}$

Takayasu arteritis typically manifests as concentric aortic wall thickening with a 'double ring' appearance on contrast CT, due to inflammation of the adventitia. A later occlusive stage is often characterised by branch vessel stenoses. ${ }^{2}$ Seronegative arthopathies are associated with subvalvular and cusp thickening, which are not present in the case. ${ }^{3}$ Infections of the aorta are rare, however, Salmonella aortitis can occur in immunocompromised patients with coexistent osteomyelitis and an atherosclerotic aortopathy which are not features of this case. IgG4-related disease is a fibroinflammatory condition associated with lymphoplasmacytic infiltrates and retroperitoneal fibrosis. ${ }^{4}$

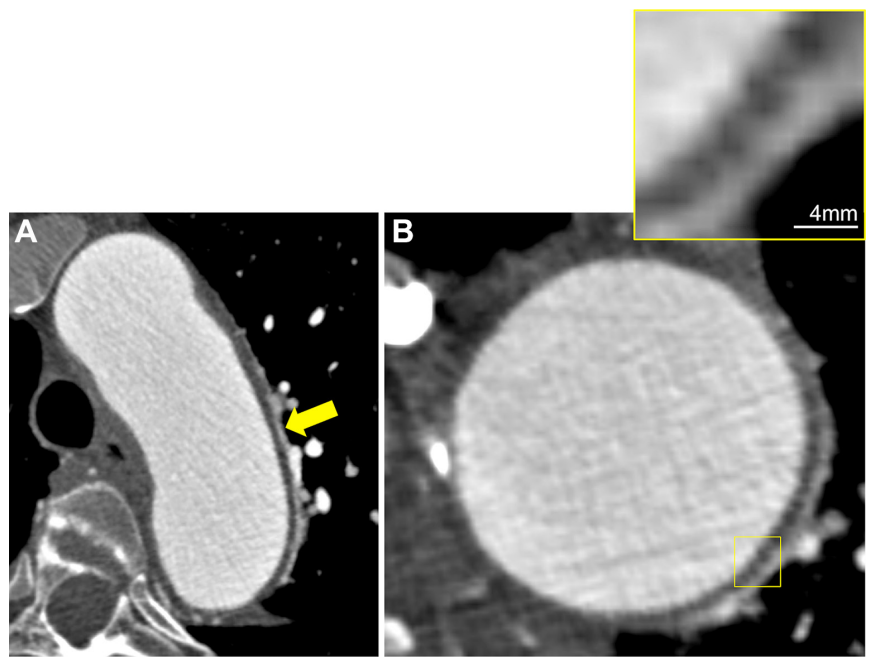

Figure 2 ECG-gated cardiac CT angiogram reconstructions of the $(A)$ aortic arch and (B) descending thoracic aorta. Circumferential intramural thickening ( $4 \mathrm{~mm}$ ) with adventitial contrast enhancement of the descending thoracic aorta (inset).
The patient underwent valve-sparing surgery with replacement of the aortic root, ascending aorta and hemiarch (see online supplementary figure 2). Aortitis is an important diagnosis to consider in the management of suspected vasculitic syndromes.

\section{Alastair J Moss, ${ }^{1}$ Renzo Pessotto, ${ }^{2}$ Andrew D Flapan ${ }^{2}$ \\ ${ }^{1}$ Centre for Cardiovascular Science, Royal Infirmary of Edinburgh, University of Edinburgh, Edinburgh, UK \\ ${ }^{2}$ Edinburgh Heart Centre, Royal Infirmary of Edinburgh, Edinburgh, UK}

Correspondence to Dr Alastair J Moss, Centre for Cardiovascular Science, University of Edinburgh, Royal Infirmary of Edinburgh, Edinburgh, EH16 4TJ, UK; alastairmoss@gmail.com

Contributors AM wrote the manuscript. RP and ADF were involved in the clinical care of the patient.

Competing interests None declared.

Patient consent Obtained.

Provenance and peer review Not commissioned; externally peer reviewed.

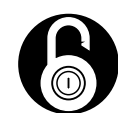

\section{OPEN ACCESS}

Open Access This is an Open Access article distributed in accordance with the Creative Commons Attribution Non Commercial (CC BY-NC 4.0) license, which permits others to distribute, remix, adapt, build upon this work non-commercially, and license their derivative works on different terms, provided the original work is properly cited and the use is non-commercial. See: http://creativecommons.org/ licenses/by-nc/4.0/

(C) Article author(s) (or their employer(s) unless otherwise stated in the text of the article) 2018. All rights reserved. No commercial use is permitted unless otherwise expressly granted.

- Additional material is published online only. To view please visit the journal online (http://dx.doi.org/10.1136/heartjnl-2017-312193).

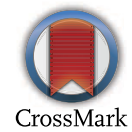

To cite Moss AJ, Pessotto R, Flapan AD. Heart 2018;104:274

Received 21 July 2017

Revised 11 September 2017

Accepted 13 September 2017

Published Online First 3 November 2017

Heart 2018;104:274. doi:10.1136/heartjnl-2017-312193

\section{REFERENCES}

1 Prieto-González S, Arguis P, García-Martínez A, et al. Large vessel involvement in biopsy-proven giant cell arteritis: prospective study in 40 newly diagnosed patients using CT angiography. Ann Rheum Dis 2012;71:1170-6.

2 Yamada I, Nakagawa T, Himeno Y, et al. Takayasu arteritis: evaluation of the thoracic aorta with CT angiography. Radiology 1998;209:103-9.

3 Tucker CR, Fowles RE, Calin A, et al. Aortitis in ankylosing spondylitis: early detection of aortic root abnormalities with two dimensional echocardiography. Am J Cardiol 1982;49:680-6.

4 Stone JH, Zen Y, Deshpande V. IgG4-related disease. N Eng/ J Med 2012;366:539-51. 